\title{
A Metric for Success
}

\section{Gary P. Carver}

U.S. DEPARTMENT OF COMMERCE Technology Administration National Institute of Standards and Technology

Metric Program

Technology Services

Gaithersburg. MD 20899 



\section{A Metric for Success}

\section{Gary P. Carver}

U.S. DEPARTMENT OF COMMERCE Technology Administration

National Institute of Standards

and Technology

Metric Program

Technology Services

Gaithersburg, MD 20899

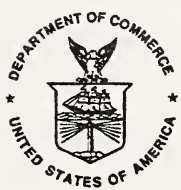

U.S. DEPARTMENT OF COMMERCE Ronald H. Brown, Secretary

TECHNOLOGY ADMINISTRATION

Mary $L$ Good, Under Secretary for Technology

NATIONAL INSTITUTE OF STANDARDS

AND TECHNOLOGY

Arati Prabhakar, Director 


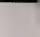




\section{A METRIC FOR SUCCESS}

by Gary P. Carver

\section{ABSTRACT}

The federal agencies are working to partner with industry to ease adoption of the metric system. The goal is to help U.S. industry to compete more successfully in the global marketplace, increase exports, and create new jobs. The strategy is to use federal procurement, financial assistance, and other business-related activities to encourage voluntary conversion. Based upon the positive experiences of firms and industries that have converted, federal agencies have concluded that metric use will yield longterm benefits that are beyond any one-time costs or inconveniences. It may be time for additional steps to move the Nation out of its dual-system comfort zone and to continue the progress toward metrication. Report includes "Metric Highlights in U.S. History."

\section{KEYWORDS}

federal agencies; metric; metric conversion; metric system; metric transition; metrication; SI; standards

Dr. Gary P. Carver is chief of the Metric Program at the National Institute of Standards and Technology. Prior to assuming responsibility for the Commerce Department's leading role in federal agency metrication, Carver was a research physicist in integrated circuit technology and a manager in the electronics and manufacturing laboratories at NIST. His goal is to successfully eliminate the need for his office as the United States completes its transition to the International System of Units (SI), the modern metric system used throughout the world. 


\section{Introduction}

The metric system cannot be avoided in international trade and commerce. It will be interesting to see how long the United States can hold out against the worldwide use of the International System of Units (SI), the modern metric system. What is even more curious is why would the world's leading industrial nation want to resist using a world standard.

\section{Worldwide Metric Momentum}

Most U.S. industries that do business abroad are predominantly metric because of global sourcing of parts, service, components, and production. Even the remaining nonmetric U.S. industries that operate internationally, such as the aerospace industry, are increasing their metric use for certain products and activities, or are being influenced by metrication in other industries.

In civil aviation, for example, commercial aircraft are mostly nonmetric, but newer designs for European passenger planes are metric and smaller general aviation aircraft and helicopters that are being build around the world are almost exclusively metric. Airport construction, including buildings and ground support systems, is being affected by the growing interest in metric conversion among commercial construction contractors and manufacturers of machinery for production and handling. Commercial construction contractors and capital equipment manufacturers are being influenced in turn by customers in other industry sectors where metric use is rapidly increasing, such as road, bridge, and public building construction and factory equipment. Also, architects and large engineering construction firms are competing for public works projects, including airports, in countries around the world where metric use is mandatory. 
Manufacturers of cars, tractors, and earth-moving equipment, including their suppliers, switched to the metric system in the 1970s and 1980s. As a result, almost all the products and components in these industries, such as engines and drive trains, are metric; although some unique components either do not have metric counterparts or come in inch sizes that fall within tolerance of standard metric sizes. For example, fasteners used in automotive applications are almost all standard metric thread and shank sizes, except for sheet metal or thread-forming screws. Some thread-forming screws are within tolerance of metric standards, although certain kinds are truly metric. All of them can fit into a hole that has a metric dimension. Metric-gauged sheet steel and other metal products are used in the automotive industry, but some common inch sizes are also used because they are within tolerance of round metric sizes. For example, $1 / 64$ th of an inch is equivalent to 0.40 millimeters (more accurately, it is 0.3969 millimeters). Similarly, $1 / 32 \mathrm{nd}$ and $1 / 16$ th are within tolerance of 0.80 and 1.60 millimeters.

Many basic parts used for mechanical equipment are metric or are readily available in metric sizes. In addition to metric fasteners, they include ball bearings, drive components, and electrical components. As metrication advances, more equipment will become metric. This will pose few problems and may be widely unnoticed, except that metric tools will be increasingly necessary and inch-size tools will be used less. Metrication will not affect equipment performance, cost, or availability.

In domestic industries that are still nonmetric, metric standards are beginning to appear because our national standards are being harmonized with international standards. Domestic industries that ignore global realities and continue designing and manufacturing with nonmetric measures will find that they risk increasing their costs. They also risk limiting themselves to a smaller pool of nonmetric supplier firms, paying more for nonstandard parts and 
materials, and having to readjust or recalibrate metric equipment and machinery from other industries to their own nonmetric specifications. Nonmetric modular products and those that interface with outside-industry products are especially vulnerable to the added costs of adapting to a metric environment.

\section{Measurement Systems: Inefficiencies and Benefits}

It has to be less efficient for a business enterprise or an industry--or a nation--to use two measurement systems instead of one. For a firm, two measurement systems usually means two sets of tools, parts, product specifications, and marketing literature, as well as repeated conversions among units. Using two measurement systems industry-wide multiplies the inefficiencies suffered by individual firms. It adds uncertainty and potential confusion to industry standards and marketing and it may lead to habitual unit conversions.

At the national level, as long as any industries use nonmetric units, educators must teach the inch-pound system, including unit conversions and manipulations with fractions. Opportunities are lost to improve the entire mathematics curriculum and train future workers in technology required by the international marketplace. The benefits are lost from using a simpler system of units.

However, the most important loss may be to the nation's standard of living. Potential customers in other nations have grown up with the metric system of measurement. Customers in foreign countries are familiar with and expect--usually prefer--products made to metric measures. They are neither familiar with nor comfortable with U.S. pints and ounces and inches and pounds. 
On the shelves of shops in other nations, our inch-pound products are at a disadvantage. In today's highly competitive global markets, any disadvantage quickly translates to lost sales and fewer exports. In some cases, such as appliances and building materials, U.S. manufacturers cannot export items that are made to nonmetric measures. This inevitably leads to less domestic economic growth, fewer new jobs, and a lower standard of living than we could otherwise enjoy.

Nevertheless, industry and the public may have reached a stable condition where they accept use of two measurement systems. The stability may be due to the perception that for the remaining nonmetric activities, temporary costs for changing to predominant metric use exceed expected benefits. The perception arises partly because the continuing costs of inch-pound use are being invisibly absorbed by current accounting methods and partly because our existing dual-measurement-system economy is passively accepted by the public. If the economic baseline were a more efficient single-system metric economy, then industry may see that temporary metric conversion costs are an investment that will reduce current costs and eventually provide a large return. Cultural attitudes will have to change to eliminate the inch-pound measurement system from our economy. If the U.S. economy is to grow, exports will have to be increased. It has been estimated that each $\$ 1$ billion in merchandise exports supports almost 20,000 jobs, over seventy million Americans work in export-related jobs, and export-related jobs have higher than average pay.

\section{Metric Equals Standardization}

New technologies, along with increasing world competition, are making it both easier and more compelling to convert to metric use. Even where international standards are still nonmetric and where it seems impossible to ever change (such as in civil aviation 
where the foot is used to measure the aircraft altitude), new technology is providing opportunities to make such large scale changes. Technology can make it possible to make massive changes that must be universal, instantaneous, and confirmed. Some examples of technologies that can enable conversions that were once considered improbable are powerful computer chips, solid modeling software for computer-aided design, microelectronics, and global positioning satellites and receivers.

Some conversions will be to round numbers of metric units, such as 1000 feet converting to 300 meters. But certain quantities will change by an exact mathematical conversion. Where international standards, safety considerations, or psychological factors are involved, it is likely that exact mathematical conversion will be used. For example, measurements in safety regulations and specifications in certified test methods are likely to remain dimensionally the same but simply be expressed in metric units.

Business enterprises that convert to the metric system usually end up saving money. Frequently, especially at first, metric conversion is a means for a company to standardize its product line and to reduce the number of products or the number of parts in its inventory. However, some U.S. companies that converted saw sales increases from unexpected new customers, particularly foreign-owned companies operating in the United States. Some companies report savings from fewer mistakes and less rework because switching to decimal metric units simplifies their work. The biggest advantages are probably the elimination of two sets of tools and the reduction in parts inventories. 


\section{The Metric System, the Federal Government, and Industry}

Just like energy, transportation, and telecommunications, the Nation's measurement system is an important element of our economic infrastructure. Therefore, it is appropriate that the Federal Government has the Constitutional power to "fix the standards of weights and measures." In exercising this power over the years, the Federal Government has acknowledged the growing use of the metric system worldwide, and has even defined U.S. inch-pound units legally in terms of metric units.

When it amended the Metric Conversion Act, Congress declared as U.S. policy that the metric system is the preferred system of weights and measures for trade and commerce. The metric-use amendments were contained in the Omnibus Trade and Competitiveness Act of 1988. They direct the federal agencies to convert programs relating to trade, industry, and commerce to the metric system. The Act allows exceptions to metric use in federal programs to avoid unintended harm to U.S. firms. For example, federal agencies are not required to use the metric system if it is "impractical or likely to cause significant inefficiencies or loss of markets to United States firms."

The federal agencies are working with industry to ease adoption of the metric system and thereby help U.S. industry compete more successfully in the global marketplace, increase exports, and create new jobs. The strategy is to use federal procurement, financial assistance, and other business-related activities to encourage U.S. firms to convert voluntarily to the metric system. 


\section{The Commerce Department Role}

In 1991, Executive Order 12770 gave the Secretary of Commerce leadership responsibility to direct and coordinate the metric conversion efforts of all federal agencies. The order also requires the Secretary to report progress annually to the President. In March 1994, the Secretary adopted a strong new metric transition plan for the Department of Commerce that significantly elevates Commerce's response to the challenge initiated by the Metric Conversion Act.

Under the new metric transition plan for the Department, the Secretary will speak publicly on the benefits and advantages of metric system use. He will seek to initiate a national debate among federal, state and local governments, industry, and the public on the adoption of the metric system.

The new plan is a road map for the metric conversion of Department of Commerce programs and functions that depend upon measurements. It ensures that Commerce acquisition regulations support the intent of the Metric Conversion Act, the executive order, and the guidance approved by the Interagency Council on Metric Policy.

Where an acquisition specifies an item that is not covered by an international standard, the product description, if it contains units of measurement, will simply use metric units (sometimes with inchpound units following in parentheses). Therefore, most purchases will be for the same products that would have been bought without metric measurements. However, the intent is not just to use metric units, but to switch to products and product sizes that are internationally standard. One visible internationally standard product that will be phased in under the new plan is standard metric size paper for letterhead, reports, and copying. 


\section{The National Institute of Standards and Technology Role}

The Metric Program at the National Institute of Standards and Technology (NIST) administers the Department of Commerce metric transition activities. Guidelines, plans, and reports are prepared to carry out both the Secretary's interagency and internal Commerce Department metric transition efforts. The NIST Metric Program coordinates the metric transition efforts of other federal agencies and leads or participates in metric transition-related activities throughout the Federal Government.

The chief of the NIST Metric Program chairs the interagency Metrication Operating Committee and its Steering Group, oversees the activities of the interagency functional subcommittees, and chairs the Department of Commerce Metric Committee. NIST also administers the Interagency Council on Metric Policy, which is chaired by the Commerce Under Secretary for Technology. In addition, the NIST Metric Program prepares and provides information about the objectives, status, and outlook of the federal metric transition, and about the metric system itself.

\section{A Metric Conversion Initiative}

Working with vendors and suppliers on metrication, the federal agencies have found that there are no major barriers to completing the conversion of nonmetric U.S. industries. However, the federal agencies have found that some firms believe U.S. customers may be unwilling to use metric measures. The experience is that U.S. customers readily accepted metric beverage containers, nutrition labeling, vitamin doses, and track and field events. 
Some firms responded to a Commerce Department survey that they are unable to justify investments in metric conversion because the benefits are not immediate. Some said that they do not plan to convert because their current customers are not demanding metric products. Companies that do not export stated that there is no need for them to change to metric units.

However the federal agencies believe that although such views may appropriately reflect individual firms' assessment of their business environments, they do not reflect the national "big picture" economic benefits that can be gained from metric conversion. Besides eliminating the costs of two measurement systems, the national benefits include removing the self-imposed trade barrier caused by a nonstandard measurement system. Based upon the positive experiences of firms and industries that have converted, federal agencies have concluded that metric use will yield longterm benefits that are beyond any one-time costs or inconveniences.

Nevertheless, no matter how broad their national vision, the federal agencies cannot establish the metric system as the preferred system in trade and commerce by themselves. They ultimately need the support of private industry and the public. That support has been slow in coming. It may be time for additional steps to move the Nation out of its dual-system comfort zone and to continue progress toward metrication.

Some possible next steps might include:

1. Greater Federal Government leadership and more visible articulation of the national vision.

2. Actions to encourage a broad national exchange on metric conversion.

3. Public forums to consider the interrelated interests and views of government, industry, and the public. 
4. A broadly based campaign to increase awareness of the economic issues related to metric use and the application of metric measures in daily life.

5. Review and revision of existing nonmetric regulations, standards, and legislation.

6. Actions to identify and remove any impediments to metric use in industry and to minimize any potential adverse economic effects.

No one wants a federal "metric bureaucracy." Instead, the desire is for including metric use in national policy initiatives.

Competitiveness, educational excellence, workforce retraining, technology commercialization, trade agreements, and international standards are all issues where metric use is important and can reasonably be included.

The NIST Metric Program provides information on the federal metric transition and on the metric system. A copy of the Commerce Department metric transition plan is available upon request from the Metric Program, National Institute of Standards and Technology, Building 411, Room A146, Gaithersburg, MD, 20899-0001 (telephone: 301-975-3690; facsimile: 301-948-1416). 


\section{Metric Highlights in U.S. History'}

1790

U.S. Constitution empowers Congress "to fix the standards of weights and measures." Thomas Jefferson submits a report on weights and measures to Congress recommending a measurement system based on multiples of ten. French commission develops metric system.

1795 France makes metric system compulsory.

1799 Congress passes "Surveyors Act," first federal weights and measures law.

1812 Napoleon suspends compulsory provisions of French metric law.

1817-1821 Congress requests Secretary of State John Quincy Adams to recommend system of weights and measures. Adams' "Report Upon Weights and Measures" recommends consideration of the metric system and establishment of an international effort to achieve uniformity in measurement systems.

1828-1832 Congress adopts Troy pound as standard for coinage. Treasury adopts yard, avoirdupois pound, and Winchester bushel as basis of customs duties.

$1840 \quad$ France reinstates mandatory metric system requirements.

${ }^{1}$ The author thanks Ken Butcher of the NIST Office of Weights and Measures for the use of his material in this table. 
$1866 \quad$ Kassen Act makes metric weights and measures "lawful throughout the United States of America" for legal and commercial transactions (but use is voluntary) and directs the Secretary of the Treasury to deliver to each state governor "one set of standard weights and measures of the metric system."

1875-1878 United States and sixteen other nations sign the "Metric Convention" or the "Treaty of the Meter."

Senate ratifies treaty and President Hayes "proclaims"

it. The treaty establishes International Bureau of Weights and Measures under the control of General Conference on Weights and Measures, and sets international standards for units of mass and length: kilogram and meter. Federal agencies respond unfavorably to Congress on use of metric system in government transactions and purchases. Mint officially adopts Troy pound as basis for coinage.

1890-1893 President Harrison accepts kilogram and meter standard artifacts at White House. Congress enacts law for steel that contains both metric and inch-pound units. Superintendent of Weights and Measures Mendenhall, with the approval of the Secretary of the Treasury, orders that international kilogram and meter legally be fundamental standards for mass and length in the United States.

1894-1896 Congress establishes electrical units based on metric system, and adopts resolution to study feasibility of adoption of metric system. A bill to adopt metric system passes but is later sent to committee.

1901 National Bureau of Standards established. 
1905 National Bureau of Standards sponsors first meeting of the National Conference on Weights and Measures.

1960 Eleventh General Conference on Weights and Measures adopts modern metric system, officially named International System of Units (SI).

1968 Congress passes "Metric Study Act" requesting Secretary of Commerce "to determine advantages and disadvantages of increased use of metric system in the United States."

1971 Department of Commerce releases National Bureau of Standards report "A Metric America--A Decision Whose Time Has Come."

1975 Congress passes "Metric Conversion Act" to foster voluntary conversion; act establishes U.S. Metric Board.

1982 President Reagan eliminates funds for board, directs Secretary of Commerce to continue Administration's metrication efforts.

1988 Congress amends Metric Conversion Act of 1975 in Omnibus Trade and Competitiveness Act.

Amendments make metric system "preferred system of weights and measures for United States trade and commerce." Act also changes National Bureau of Standards to "National Institute of Standards and Technology."

1991 President Bush acts to fill federal transition leadership void by issuing Executive Order 12770, "Metric Usage in Federal Government Programs." 
Congress amends Fair Packaging and Labeling Act to require both metric and inch-pound units on most consumer-item package labels. 


